\title{
Mapping Urban Excavation Induced Deformation in 3D via Multiplatform InSAR Time-Series
}

\author{
Kendall Wnuk ${ }^{1}$, Wendy Zhou ${ }^{1, *(1)}$ and Marte Gutierrez ${ }^{2}$ \\ 1 Department of Geology and Geological Engineering, Colorado School of Mines, Golden, CO 80401, USA; \\ kwnuk@usgs.gov \\ 2 Department of Civil and Environmental Engineering, Colorado School of Mines, Golden, CO 80401, USA; \\ mgutierr@mines.edu \\ * Correspondence: wzhou@mines.edu
}

Citation: Wnuk, K.; Zhou, W.; Gutierrez, M. Mapping Urban Excavation Induced Deformation in $3 \mathrm{D}$ via Multiplatform InSAR Time-Series. Remote Sens. 2021, 13, 4748. https://doi.org/10.3390/ rs13234748

Academic Editor: João

Catalão Fernandes

Received: 25 October 2021

Accepted: 19 November 2021

Published: 23 November 2021

Publisher's Note: MDPI stays neutral with regard to jurisdictional claims in published maps and institutional affiliations.

Copyright: (c) 2021 by the authors. Licensee MDPI, Basel, Switzerland. This article is an open access article distributed under the terms and conditions of the Creative Commons Attribution (CC BY) license (https:/ / creativecommons.org/licenses/by/ $4.0 /)$.

\begin{abstract}
Excavation of a subway station and rail crossover cavern in downtown Los Angeles, California, USA, induced over $1.8 \mathrm{~cm}$ of surface settlement between June 2018 and February 2019 as measured by a ground-based monitoring system. Point measurements of surface deformation above the excavation were extracted by applying Interferometric Synthetic Aperture Radar (InSAR) time-series analyses to data from multiple sensors with different wavelengths. These sensors include C-band Sentinel-1, X-band COSMO-SkyMed, and L-band Uninhabited Aerial Vehicle SAR (UAVSAR). The InSAR time-series point measurements were interpolated to continuous distribution surfaces, weighted by distance, and entered into the Minimum-Acceleration (MinA) algorithm to calculate 3D displacement values. This dataset, composed of satellite and airborne SAR data from $X, C$, and L band sensors, revealed previously unidentified deformation surrounding the 2nd Street and Broadway Subway Station and the adjacent rail crossover cavern, with maximum vertical and horizontal deformations reaching $2.5 \mathrm{~cm}$ and $1.7 \mathrm{~cm}$, respectively. In addition, the analysis shows that airborne SAR data with alternative viewing geometries to traditional polar-orbiting SAR satellites can be used to constrain horizontal displacements in the North-South direction while maintaining agreement with ground-based data.
\end{abstract}

Keywords: InSAR; subsidence; tunneling; optimization; sequential excavation method

\section{Introduction}

The increasingly extensive archives of SAR data collected by various sensors on spaceborne and airborne platforms offer a variety of wavelengths and distinct viewing geometries from which surface deformation measurements can be made. Over the past 20 years, advances in time-series processing methods, including the Small Baseline (SBAS) subset technique and Persistent Scatterer Interferometry (PSI), have provided the ability to make deformation measurements with millimeter-scale accuracy and precision [1-6]. As datasets from more sensors at greater spatial and temporal resolutions become available, the question arises of how to combine complementary pieces of information within different SAR datasets effectively. The combination of displacement data from multiple SAR platforms, i.e., from different line of sight (LOS) vectors, can improve our ability to resolve the East, North, and Up components of the observed surface displacements [7]. This combination is necessary for comparison to ground-based datasets and overcomes one of the main limitations of InSAR, in which a dataset from one track can measure displacements only in a single LOS projection.

Previous literature has shown measurement consistency between multiple SAR datasets [8-17], proven the ability to integrate satellite and ground-based geodetic data [18-40], and offered technical solutions for combining satellite-InSAR-based measurements into vertical, 2D, or 3D displacements [41-51]. Early successes in extracting 2D displacements were carried out by combining both left and right-looking acquisitions from 
ascending and descending orbits [41]. Other techniques have used pixel offset tracking to overcome low N-S deformation sensitivity. However, these methods require deformations on the order of $10 \mathrm{~cm}$ or more and therefore are most often applied to large and temporally discrete deformation phenomena such as co-seismic or volcanic deformation $[42,44]$. More recent advances include the multidimensional small baseline (MSBAS) subset technique [52,53] and the Minimum-Acceleration (MinA) algorithm [54,55], both of which operate by combining multiple InSAR time-series datasets and solving a set of underdetermined linear equations via Tikhonov regularization or singular value decomposition. By combining ascending and descending tracks from multiple InSAR datasets, these algorithms can extract vertical and E-W horizontal displacements.

The primary obstacles to extracting true 3D displacements using only InSAR data are twofold. First, most InSAR sensors are side-looking systems onboard satellites traveling along polar orbit paths in a primarily N-S direction, preventing LOS measurements outside of a primarily E-W plane and therefore obscuring horizontal deformation in the N-S direction [56]. Second, the combination of multiple InSAR time-series can require an overlap between Persistent Scatterer (PS) pixel locations across multiple datasets. This combination can be especially tricky considering the variety of wavelengths and spatial resolutions from available sensors, each with inherent advantages and disadvantages, depending on the setting in which they are applied [57-60]. Acquiring sufficient density of PS pixels between separate InSAR datasets can be a challenge, especially when applying time-series techniques in environments with variable backscatter amplitude $[4,61]$.

Presented here is a method to overcome each obstacle by (1) applying Uninhabited Aerial Vehicle SAR (UAVSAR) data $[18,62-70]$ with primarily N-S LOS orientations, in combination with Sentinel-1 and COSMO-SkyMed data, to better constrain displacements in the N-S direction and (2) inverse distance weighting each path of InSAR datasets, based on PS pixel location, in order to use all available data. The weighted datasets are then entered into the MinA algorithm to calculate 3D displacement values [7,54,55]. This method is tested on a spatially acute $\left(30,000 \mathrm{~m}^{2}\right)$ subsidence event in downtown Los Angeles, California, and compared to available Ground Surface Settlement Point (GSSP) vertical settlement observations to quantitatively assess method accuracy and precision. In this framework, combined InSAR datasets can monitor 3D deformations of highly urbanized zones with great spatial and temporal resolution.

\section{Study Area}

The Regional Connector Transit Corridor (RCTC) project consists of a 3-km tunnel connecting the blue and gold metro rail lines in downtown Los Angeles, California, USA (Figure 1). The construction includes a shallow ( 15 m top depth) $90 \mathrm{~m}$ long, $17.7 \mathrm{~m}$ wide, $11 \mathrm{~m}$ tall crossover structure on which construction began after twin $6.7 \mathrm{~m}$ diameter tunnels were bored by an earth pressure balance tunnel-boring machine. Boreholes along 2nd Street contain a top layer of artificial fill ranging from 1-3 m thick that overlies a 2-7 m thick deposit of poorly sorted alluvial sand. A perched aquifer is found within the alluvial sands 3-4 $\mathrm{m}$ below street level between Hill Street and Main Street. The regional groundwater table begins near the interface between the alluvial sands and the underlying weathered siltstone bedrock of the Fernando formation [71]. 


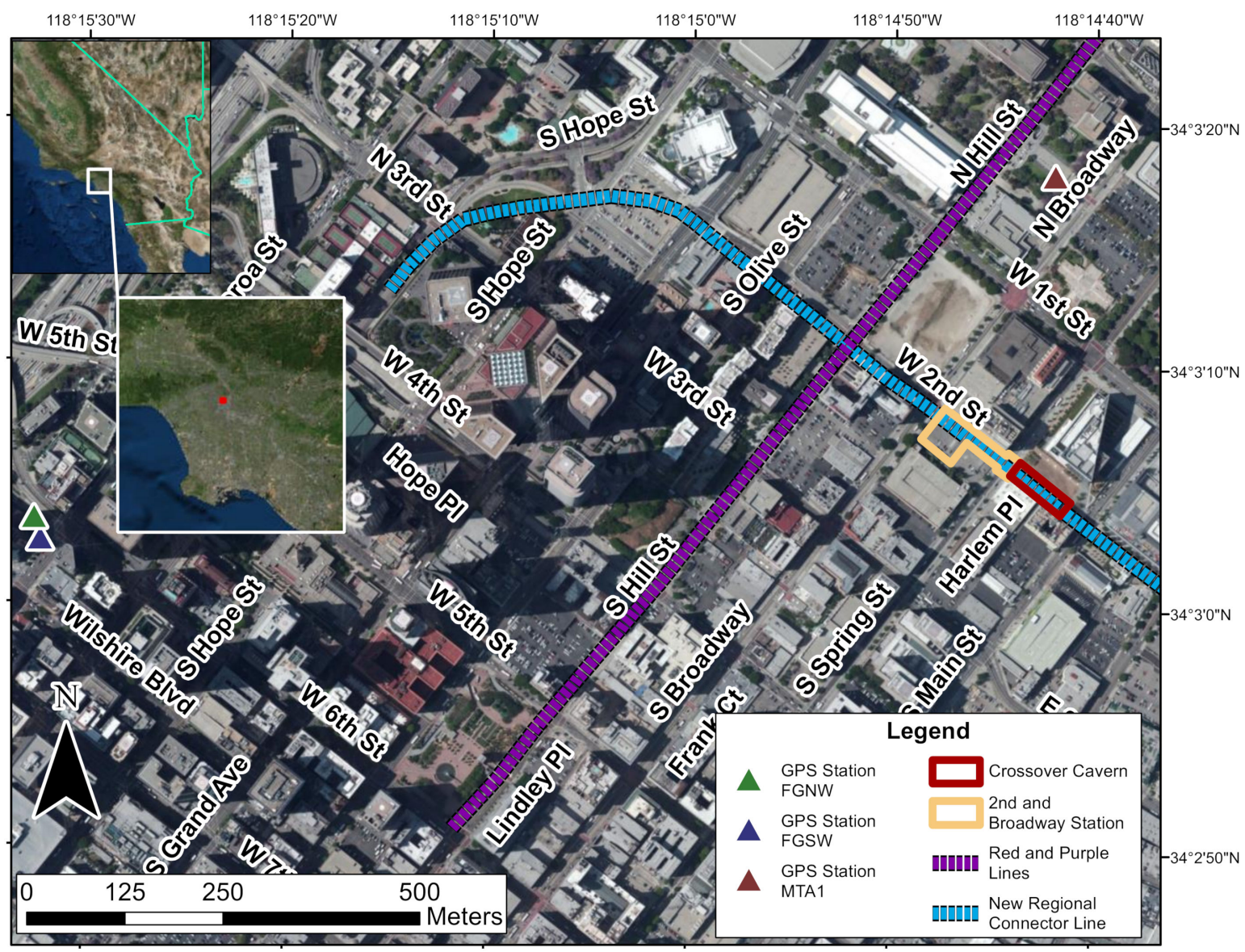

Figure 1. Los Angeles study area, located at the red point in the inset image. Also shown are the subway extension and nearby GPS stations. Background images from Esri, DigitalGlobe, GeoEye, Earthstar Geographics, CNES/Airbus, USDA, USGS, AeroGRID, IGN, and the GIS user community.

Adjacent to the crossover cavern is the 2nd and Broadway station, for which excavation was completed in July 2018 using the cut and cover method. Sequential excavation of the crossover cavern took place from 30 May 2018 to 14 March 2019, after which 30 and $46 \mathrm{~cm}$ liners of shotcrete and concrete, respectively, were installed. Sequential excavation follows principles of the observational method, requiring a complex monitoring system with extensive instrumentation, including a network of GSSPs and automated total stations capable of making settlement measurements with an accuracy of $\pm 0.7 \mathrm{~mm}$ [72]. This monitoring system captured an increase in surface subsidence coincident with the crossover cavern excavation. Between June 2018 and February 2019, a vertical settlement magnitude of $1.8 \mathrm{~cm}$ was measured along 2nd Street directly above the cavern by GSSP (Figure 2), with peak deformation rates exceeding $2.5 \mathrm{~cm} / \mathrm{yr}$ [72]. Subsidence rates measured in this location during 2018-2019 are much higher than regional subsidence rates typically found in southern California due to anthropogenic activities, including groundwater pumping and oil extraction [24,73]. The nearest available GPS data from stations MTA1, FGNW, and FGSW (Figure 1) possess average subsidence rates of $-0.29,-0.16$, and $-0.3 \mathrm{~cm} / \mathrm{y}$, respectively, for all available data between 2009 and 2021 (Figure 3) [74,75], indicating that accelerated deformation rates above the crossover cavern are primarily caused by excavation activities. 

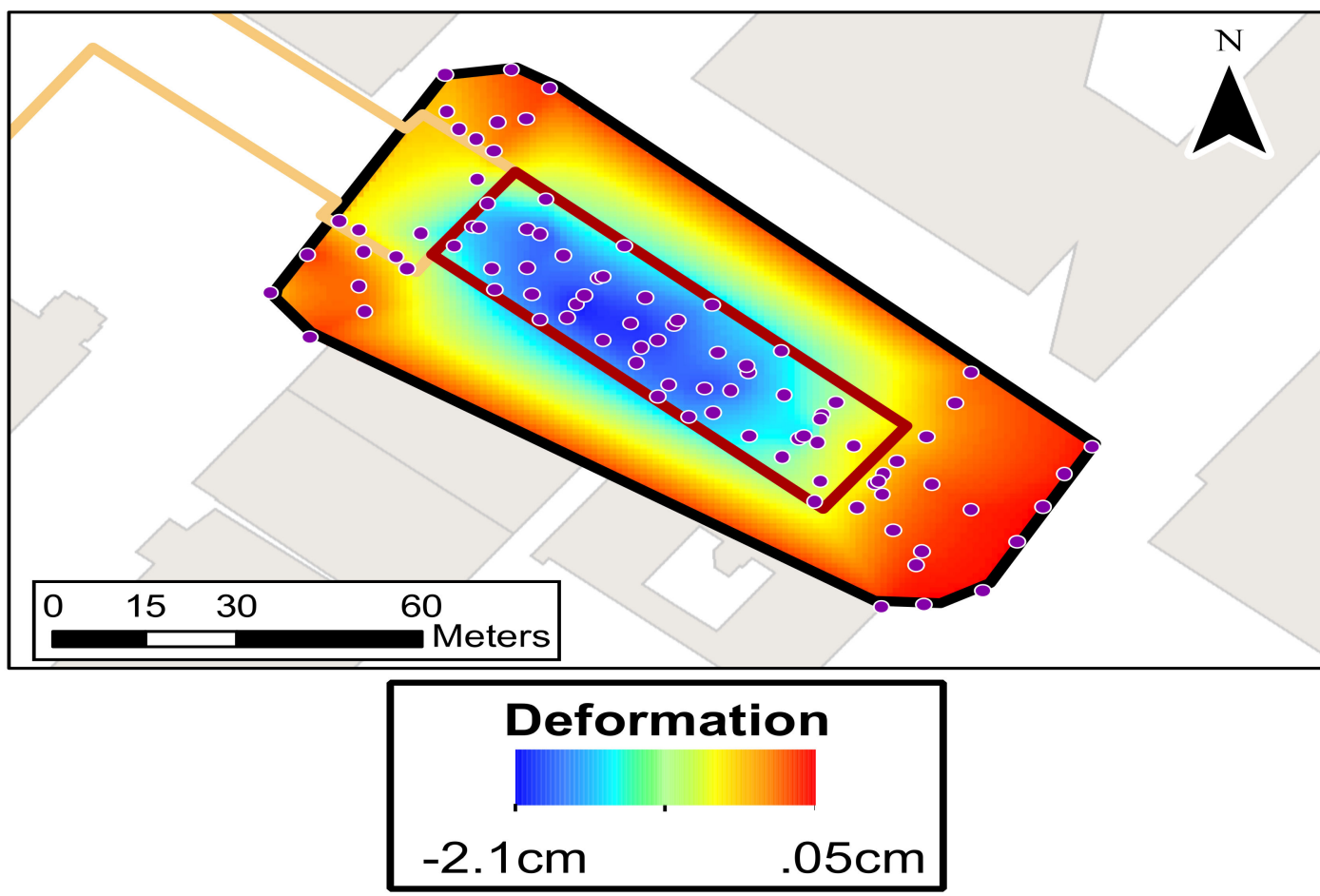

Figure 2. GSSP measurement locations and the interpolated surface of vertical displacements measured between 25 June 2018 and 25 February 2019.

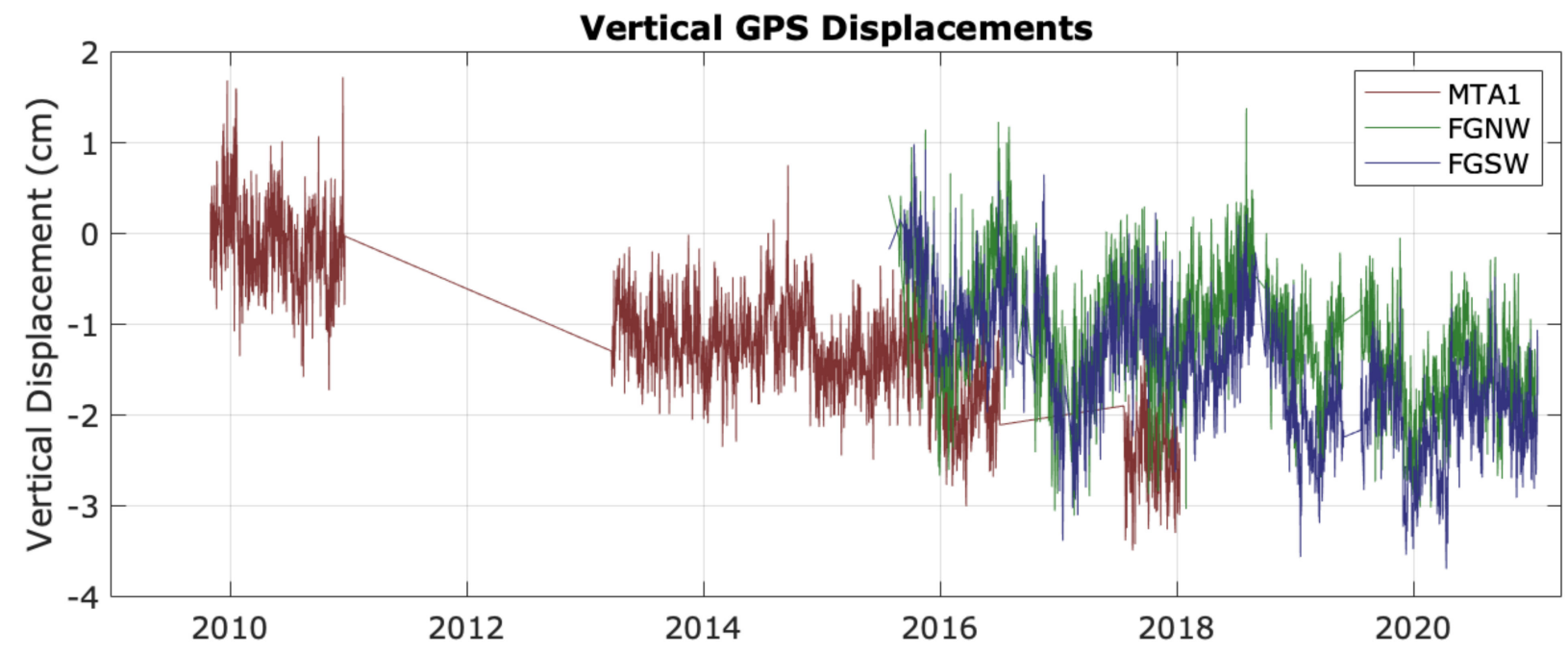

Figure 3. GPS data from stations MTA1, FGNW, and FGSW from 2009 to 2021.

The spatial extent and magnitude of ground deformation caused by tunneling activities are primarily influenced by the size and depth of excavation, geology, and hydrologic setting. Tunneling projects in urban environments generally yield relatively low magnitude settlements, as extra precautions are taken to avoid damaging overlying infrastructure. To more fully explore this deformation event, SAR data were synergistically combined from three sensors: Sentinel-1, UAVSAR, and COSMO-SkyMed. Each sensor and path provided a distinct viewing geometry (Table 1). LOS deformation time-series of all data paths were entered into a modified version of the MinA multiplatform InSAR algorithm to overcome the unique challenges presented by urban settings and yield accurate 3D displacement information. The InSAR-derived 3D displacements were compared to the 
GSSP dataset to assess the data accuracy and test the applicability of the MinA algorithm on small magnitude urban subsidence events.

Table 1. Information of the Sentinel-1, COSMO-SkyMed and UAVSAR datasets.

\begin{tabular}{|c|c|c|c|c|c|c|c|c|}
\hline Sensor & Path & $\begin{array}{c}\text { LOS } \\
\text { Azimuth } \\
(\varphi)\end{array}$ & $\begin{array}{l}\text { Radar In- } \\
\text { cidence } \\
\text { Angle } \\
(\vartheta)\end{array}$ & $\begin{array}{l}\text { Spatial } \\
\text { Resolution } \\
\text { (m) }\end{array}$ & Time Span & $\begin{array}{c}\text { Number of } \\
\text { Acquisi- } \\
\text { tions }\end{array}$ & $\begin{array}{l}\text { Maximum } \\
\text { Baseline } \\
\quad(\mathrm{m})\end{array}$ & $\begin{array}{l}\text { PS Density } \\
\left(\mathrm{PS} / \mathrm{km}^{2}\right)\end{array}$ \\
\hline $\begin{array}{l}\text { Sentinel- } \\
1\end{array}$ & 137 & $77^{\circ}$ & $44^{\circ}$ & $2.3 \times 14.1$ & $\begin{array}{c}9 \text { January 2018-3 } \\
\text { July } 2019\end{array}$ & 66 & 163 & 2550 \\
\hline $\begin{array}{c}\text { Sentinel- } \\
1\end{array}$ & 71 & $283^{\circ}$ & $39^{\circ}$ & $2.3 \times 14.1$ & $\begin{array}{c}10 \text { January } \\
\text { 2018-22 June } \\
2019\end{array}$ & 45 & 126 & 3164 \\
\hline $\begin{array}{c}\text { Sentinel- } \\
1\end{array}$ & 64 & $77^{\circ}$ & $34^{\circ}$ & $2.3 \times 14.1$ & $\begin{array}{c}\text { 4 January } \\
\text { 2018-28 June } \\
2019\end{array}$ & 40 & 116 & 2240 \\
\hline $\begin{array}{l}\text { COSMO- } \\
\text { SkyMed }\end{array}$ & - & $279^{\circ}$ & $53^{\circ}$ & $1.7 \times 2.0$ & $\begin{array}{c}12 \text { January } \\
\text { 2018-5 July } 2019\end{array}$ & 25 & 758 & 8028 \\
\hline UAVSAR & 08523 & $356^{\circ}$ & $55^{\circ}$ & $1.7 \times 0.6$ & $\begin{array}{c}23 \text { April 2009-21 } \\
\text { February } 2019\end{array}$ & 15 & $\mathrm{~N} / \mathrm{A}$ & 41,086 \\
\hline UAVSAR & 26524 & $174^{\circ}$ & $52^{\circ}$ & $1.7 \times 0.6$ & $\begin{array}{c}23 \text { April 2009-21 } \\
\text { February } 2019\end{array}$ & 18 & $\mathrm{~N} / \mathrm{A}$ & 38,124 \\
\hline
\end{tabular}

\section{Data and Methods}

Measurements of ground deformation associated with excavations for the RCTC project were acquired by processing Single Look Complexes (SLCs) from 3 paths of Sentinel-1, 2 paths of UAVSAR, and a single descending path of COSMO-SkyMed data (Table 1). Each path was separately processed using repeat pass differential interferometry. GAMMA software [76,77] was used to create a series of single master interferograms from all data paths. A single master date was chosen for each data path, and slave images were co-registered to the geometry of the chosen master scenes. Topographic phase contribution was removed via the USGS 3D Elevation Program (3DEP) $1 \mathrm{~m}$ resolution Digital Elevation Model (DEM, Available online: http:/ / nationalmap.gov (accessed on 3 October 2019)) produced using Lidar data acquired between 27 September 2015 and 18 October 2016. GAMMA's Interferometric Point Target Analysis (IPTA) [77,78] was used to create a time-series of Persistent Scatterers (PS). PS pixels were identified using the Mean to Standard-deviation Ratio (MSR) of the radar intensity backscatter. A threshold MSR value of 1.1 was used to select pixels with low temporal variability, high-intensity backscatter that provided stable phase returns over the time period of interest. SLC values at PS pixel locations were extracted and written to a point data stack. Initial differential interferograms were formed and analyzed in the temporal domain to calculate the linear dependence between the perpendicular baseline and phase for each PS pixel. This linear relationship between phase and perpendicular baseline occurs due to the presence of errors within the DEM used to remove topographic phase contributions, and as such, was calculated to estimate and remove the DEM error. These corrections were subsequently used to update calculated perpendicular baseline values. Reference pixels were selected for each sensor as a basis for phase unwrapping (Figure 4). These reference pixels were selected based on their phase stability over the time period of interest, as well as the physical location, to ensure consistency across all datasets. Linear deformation rates were then calculated for each pixel. Residual phase change, considered as a deviation from the linear deformation rate, is composed of atmospheric contamination, baseline measurement errors, any non-linear deformation, and random noise. As the atmospheric phase contribution from the master scene correlates in space and time, it was extracted using a low-pass temporal filter of the residual phase, then removed from all interferograms. The process was then iterated using the corrected DEM, updated perpendicular baselines, 
and atmosphere-corrected interferograms. Final deformation values were produced via a phase unwrapping algorithm based on minimum cost flow techniques applied to a Delaunay triangular network.

Sentinel-1 (Path 137)

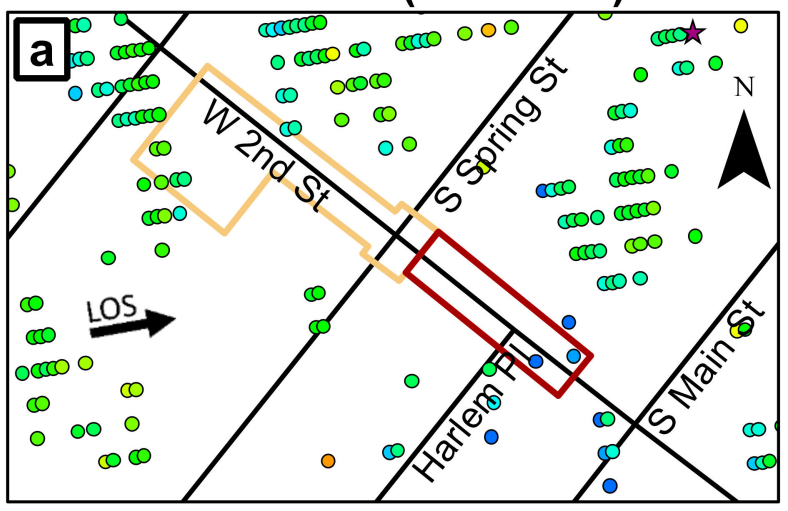

Sentinel-1 (Path 71)

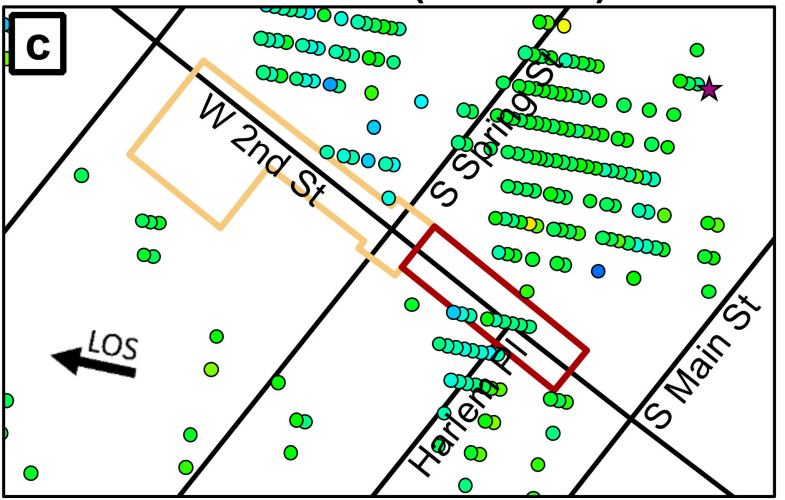

UAVSAR (Path 08523)

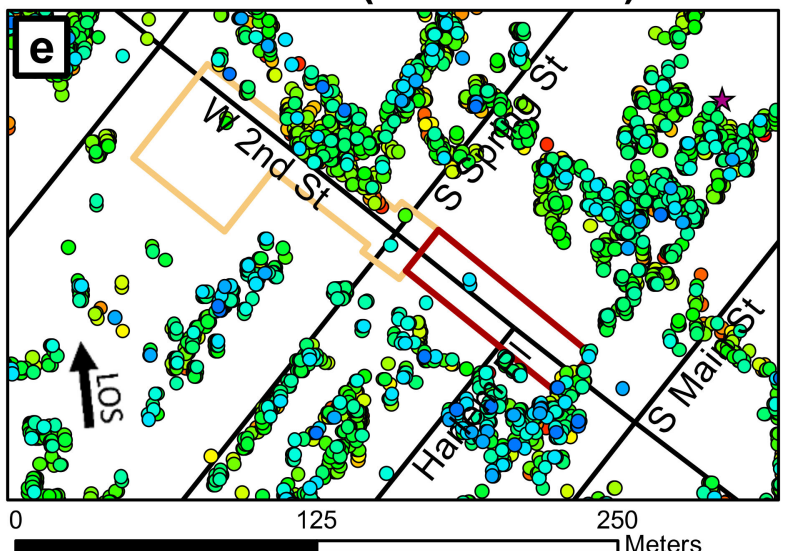

Sentinel-1 (Path 64)

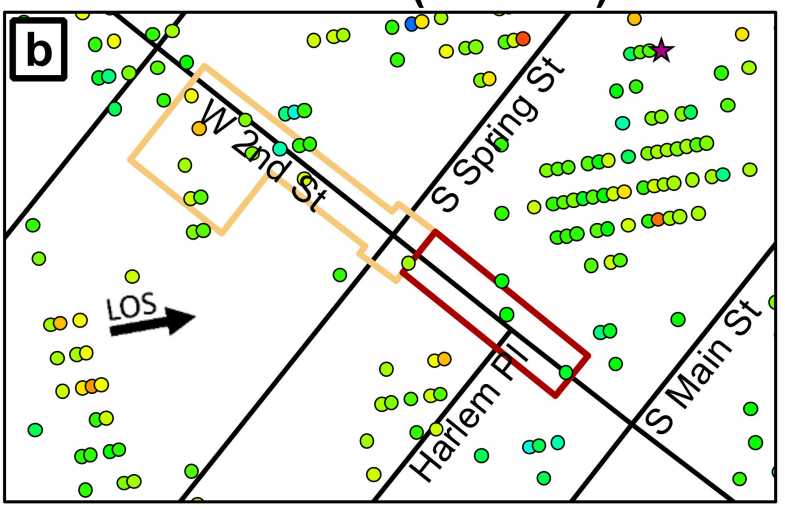

Cosmo-SkyMed

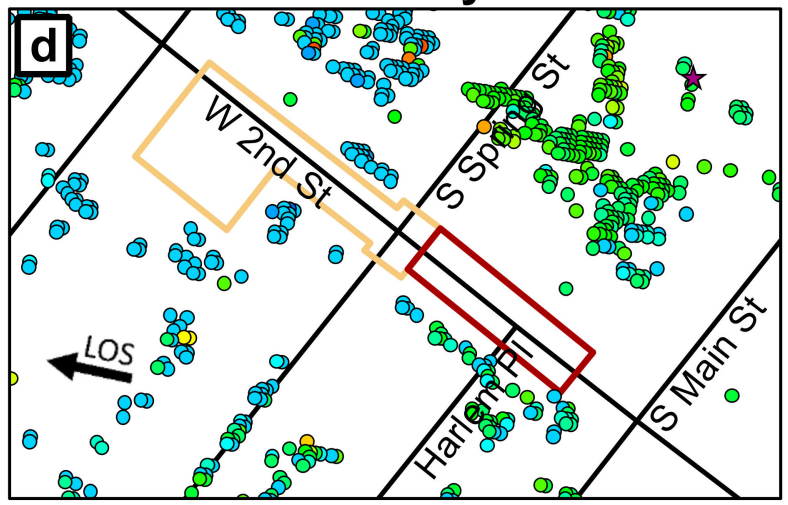

UAVSAR (Path 26524)

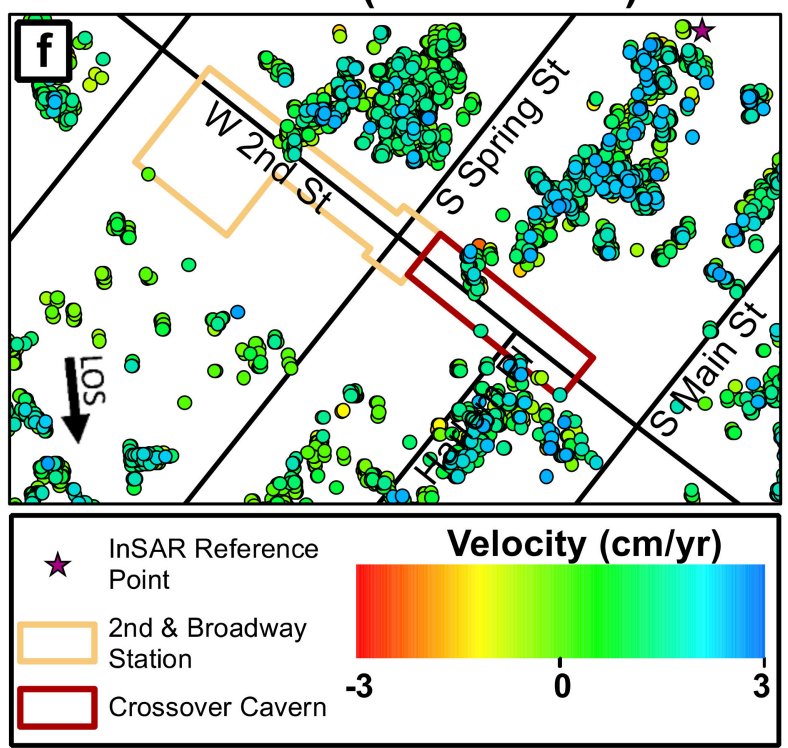

Figure 4. (a-f) Persistent scatterer pixel locations and LOS velocities, reference pixel locations, and LOS azimuth vectors associated with spaceborne and airborne InSAR datasets. LOS velocities shown are averaged over the time period between 16 November 2018 and 21 February 2019. Negative LOS velocities, shown in warmer colors, indicate motion toward the SAR sensor. Positive LOS velocities, shown in cooler colors, indicate motion away from the SAR sensor. 
After the LOS deformation time-series of PS pixels were constructed for all input datasets, each dataset was then individually linearly interpolated to a common $1 \mathrm{~m}$ gridded surface and combined in a post-processing stage using the MinA algorithm to calculate 3D deformation. As the MSBAS technique requires simultaneous processing and unwrapping many interferograms, the MinA algorithm was used due to its ability to ingest PSI timeseries data and its simple post-processing application. The $1 \mathrm{~m}$-grid size was selected to ensure spatial detail from the highest resolution sensors was preserved within the dataset and to match the resolution of the DEM used to remove the topographic phase contribution. LOS displacement rates were calculated for all input data at each acquisition time across all datasets. Because spatial resolution and LOS differed for each input dataset, PS pixel locations and scatterers also varied (Figure 4).

This variability prevented any one sensor from viewing the entirety of the deforming area and required that each dataset be weighted by inverse distance from the nearest PS pixel. This is the primary change from the original MinA algorithm, which uses interferometric coherence as the primary weighting factor. Weighted LOS displacement rates were then connected to the unknown 3-D velocities, creating a system of underdetermined independent linear equations:

$$
\left[\begin{array}{c}
d_{E} \\
d_{N} \\
d_{U}
\end{array}\right]=\left[\begin{array}{ccc}
\Gamma d_{L O S^{(1)}} \sin \vartheta^{(1)} \cos \varphi^{(1)} & \Gamma d_{L O S^{(1)}} \sin \vartheta^{(1)} \sin \varphi^{(1)} & -\Gamma d_{L O S^{(1)}} \cos \vartheta^{(1)} \\
\Gamma d_{L O S^{(2)}} \sin \vartheta^{(2)} \cos \varphi^{(2)} & \Gamma d_{L O S^{(2)}} \sin \vartheta^{(2)} \sin \varphi^{(2)} & -\Gamma d_{L O S^{(2)}} \cos \vartheta^{(2)} \\
\vdots & \vdots & \vdots \\
\Gamma d_{L O S^{(n)}} \sin \vartheta^{(n)} \cos \varphi^{(n)} & \Gamma d_{L O S^{(n)}} \sin \vartheta^{(n)} \sin \varphi^{(n)} & -\Gamma d_{L O S^{(n)}} \cos \vartheta^{(n)}
\end{array}\right]
$$

where $\Gamma$ is the weighting factor determined by the inverse distance to the nearest PS pixel, and $\vartheta$ and $\varphi$ are the radar incidence angle and LOS azimuth, respectively, of the $n$ LOS displacement time-series [54]. Equations were solved in the least-squares sense by using first-order Tikhonov regularization [79]. Regularization was achieved by imposing constraints to minimize the acceleration of 3D displacements between acquisitions. These constraints were imposed using the L-curve method [80,81], whereby a range of regularization coefficients are applied to the input system of linear equations. This creates a series of potential solutions, ranging from solutions that minimize residual error without constraining displacement acceleration to solutions that minimize acceleration but possess greater residual error (Figure 5). All potential solutions plot along an L-shaped curve, with the optimum solution located at the bottom left corner. The solution found at the corner of the L-curve is optimized because it provides the most precisely balanced solution between minimizing residual error and satisfying the side constraint, which in this case is the minimization of displacement acceleration. This analysis was performed using the regularization tools Matlab package [82]. Once estimated, the calculated velocities were independently time-integrated to extract a single 3D deformation time-series.

All available UAVSAR acquisitions were used in order to produce a deformation time-series, but only four acquisitions were made during the time period of interest, on 16 November 2018 and 21 February 2019 for both UAVSAR data paths. Due to the poor temporal resolution of the UAVSAR data, they are only available to constrain N-S horizontal deformation during the time between these acquisitions. Before 16 November 2018 and after 21 February 2019, N-S acceleration values were assumed to be negligible in order to account for the low sensitivity of satellite InSAR measurements in this direction [77]. To assess the accuracy and precision of the applied method, calculated vertical deformations from InSAR data were compared to and differenced with those from a network of GSSP that captured the subsidence event in real-time. 


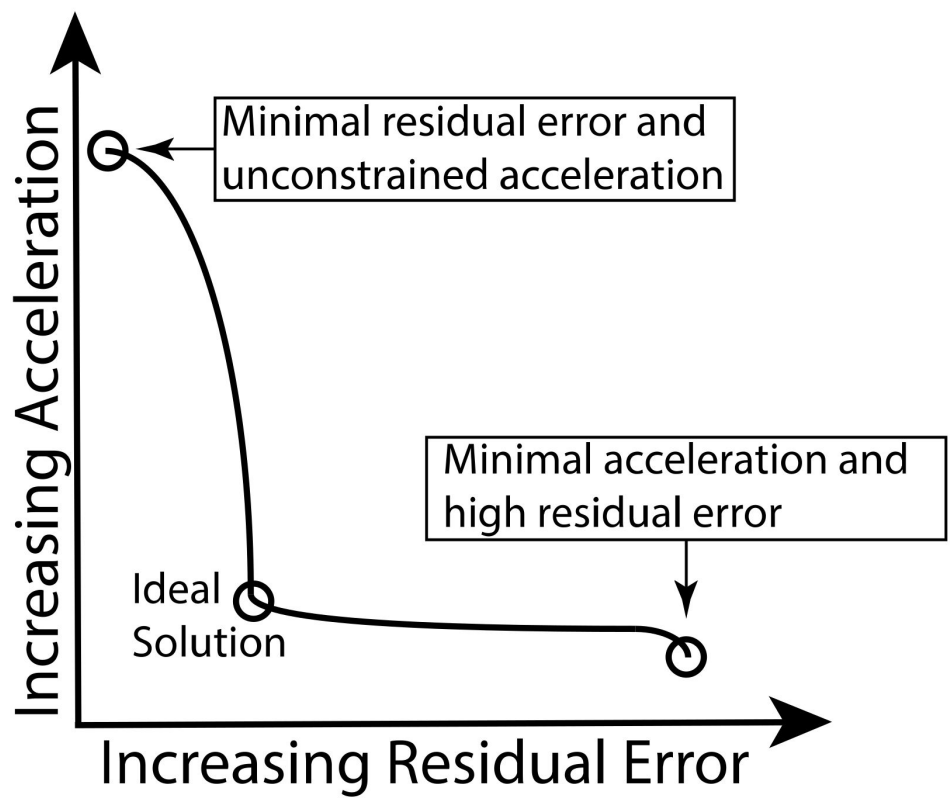

Figure 5. Example L-curve showing range of possible solutions.

\section{Results}

Calculated 3D deformations from all InSAR datasets reveal the temporal and spatial extents of subsidence related to excavation activities (Figure 6). Horizontal and vertical deformations were observed to reach beyond the boundaries of both the crossover cavern and the ground-based dataset, encompassing an area of approximately $200 \mathrm{~m}$ by $150 \mathrm{~m}$. From 16 November 2018 to 21 February 2019, the period of time during which UAVSAR data are available to constrain N-S deformation, a maximum vertical deformation of $1.2 \mathrm{~cm}$ was measured directly above the crossover cavern near point PD (Figure 7). As this location is near the center of the subsiding area, observed deformation is primarily vertical, and very little E-W or N-S horizontal deformation is calculated. Maximum horizontal deformations reach $0.5 \mathrm{~cm}$ at points PF, PC, PB, and PE for the North, South, East, and West deformation components, respectively. Calculated horizontal displacements are consistent with a subsidence event, where horizontal motions centered around the vertical settlement are directed towards each other. Localized pockets of vertical subsidence, such as the area near point PC, coincide with spatially variable horizontal deformation. Computed N-S deformation contains a greater degree of spatial variability than E-W deformation. All deformation components contain greater amounts of noise and spatial heterogeneity on buildings. 

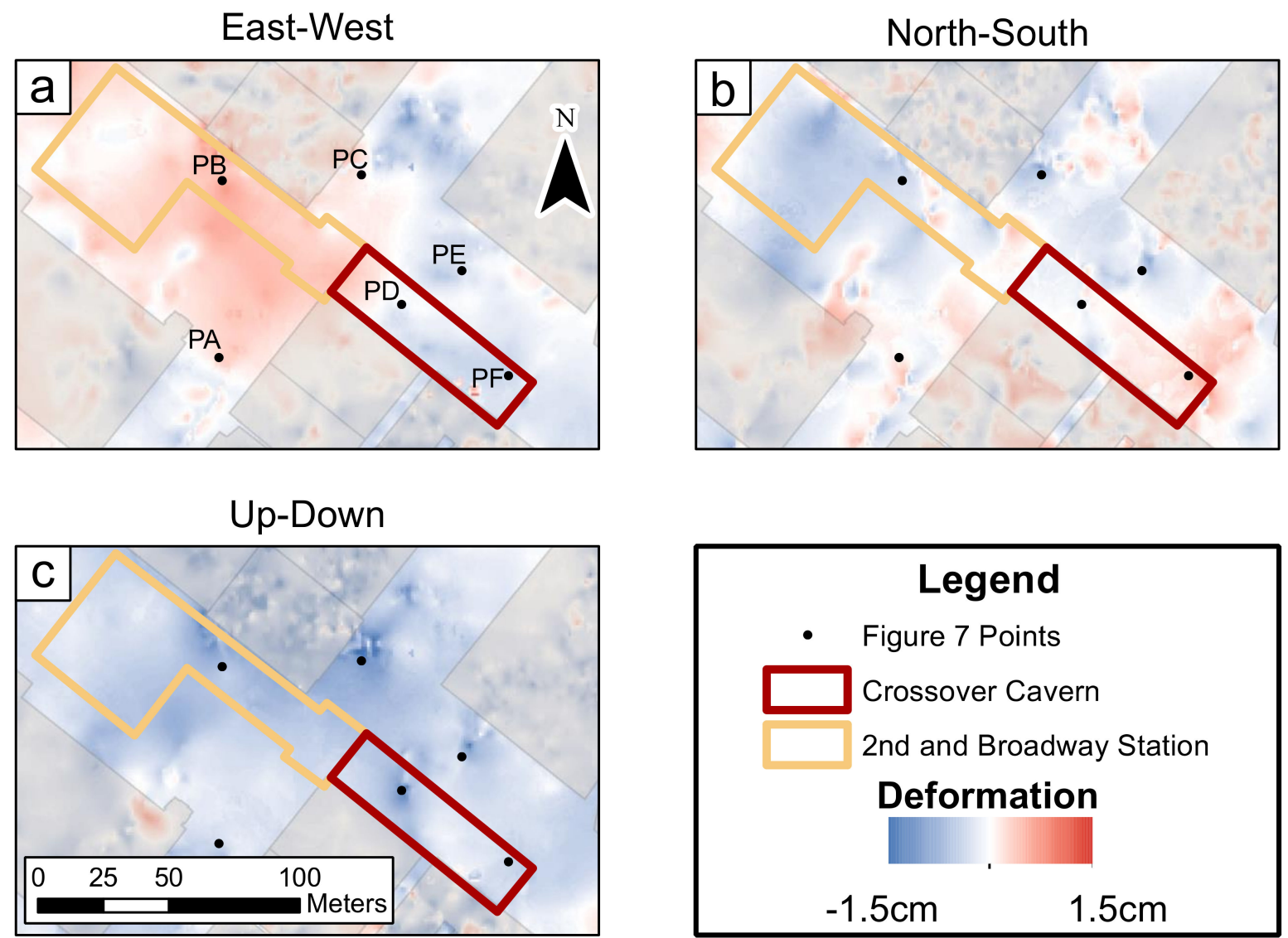

Figure 6. Map of surface deformation calculated from InSAR data spanning 16 November 2018 to 21 February 2019 in (a) East-West, (b) North-South, and (c) Up-Down directions.

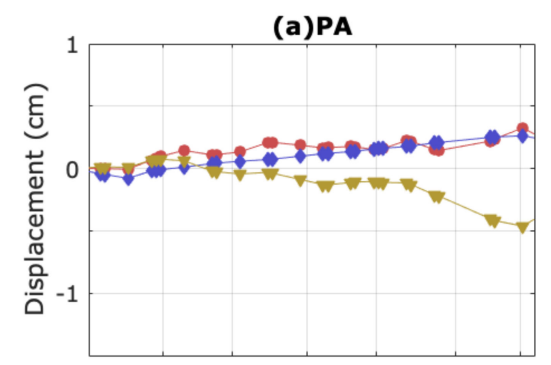

(d)PD

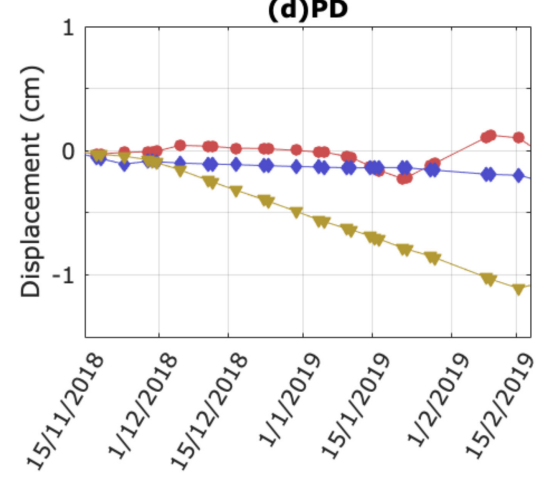

(b)PB

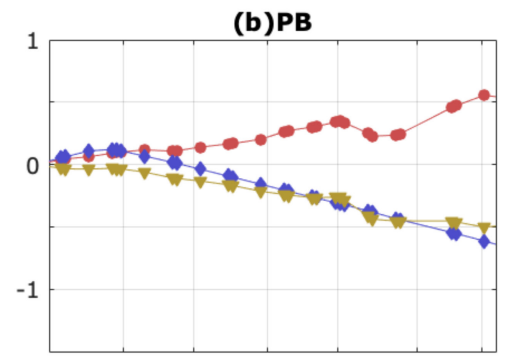

(e)PE

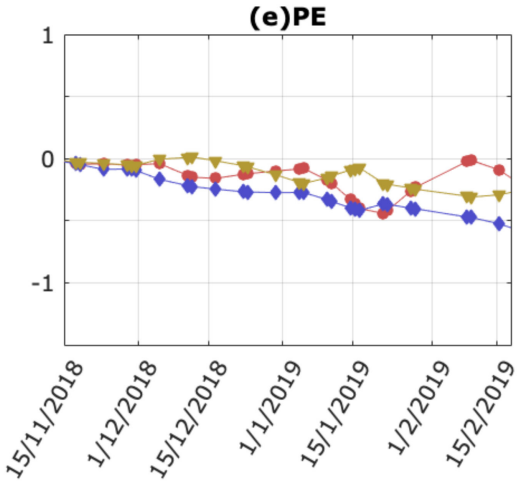

(c)PC

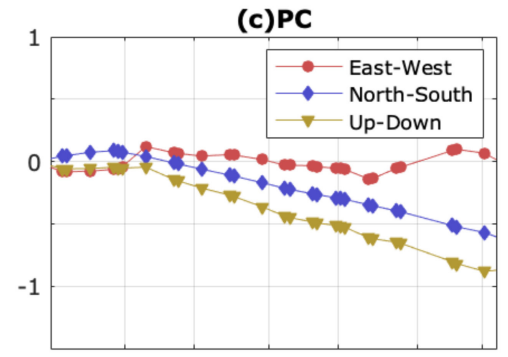

(f)PF

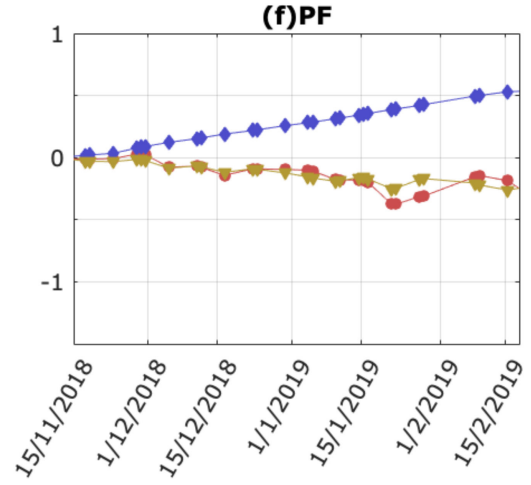

Figure 7. (a-f) East-West, North-South, and Up-Down deformation components of point locations indicated in Figure 6. 
Comparison between vertical InSAR and GSSP data shows the datasets are in good agreement, with a maximum absolute difference of $1.15 \mathrm{~cm}$ at point $\mathrm{P} 1$ and a maximum average difference of $0.53 \mathrm{~cm}$ at point P8 (Figures 8 and 9). Spatially, InSAR data tend to underestimate settlement in areas directly overlying the central portion of the crossover cavern while slightly overestimating settlement northwest and southeast of the cavern. Points P1 and P2 undergo a period of slight uplift in Fall 2018, which is captured in both the InSAR and GSSP data but overestimated by InSAR by several $\mathrm{mm}$. Around the same time period, subsidence rates at points P3-P7 are observed to decrease in the GSSP data, a trend that is well captured by InSAR as well. Subsidence rates near the center of the crossover cavern remain constant in the GSSP data, but InSAR calculated subsidence rates decrease or even show periods of uplift (Figure $9 \mathrm{~h}$ ). This is the primary discrepancy between the InSAR and GSSP datasets, further illustrated by consistent underestimation of subsidence at points surrounding point P8 (Figure 8). Points P9-P12 show lower magnitudes of surface deformation but generally, show good agreement between InSAR and GSSP data.

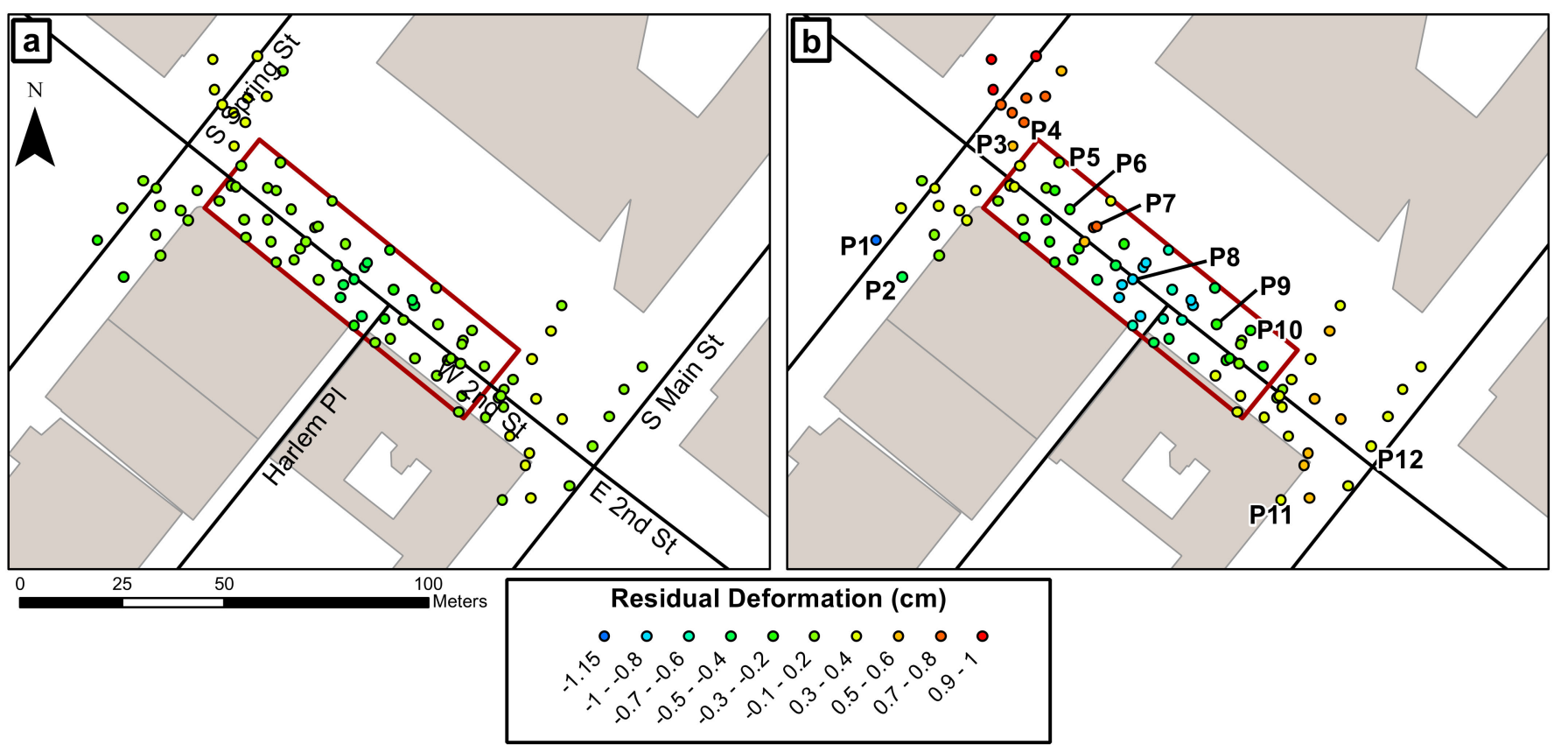

Figure 8. (a) Mean residual deformation (b) maximum residual deformation after differencing ground-based and InSAR vertical deformation data. Negative residuals, shown by cooler colors, indicate underestimation. Positive residuals, shown by warmer colors, indicate an overestimation of settlement by InSAR. Deformation time-series for points P1-P12 shown in Figure 9.

InSAR data reveal vertical deformation on the northwestern side of the cavern, near points P3 and P4, began as early as January 2018 and maintained an average subsidence rate of $1.3 \mathrm{~cm} / \mathrm{yr}$ until the completion of the crossover cavern. This early period of subsidence is not present throughout the entirety of the study area. Early subsidence reaches as far to the east as point P9 but is not observed in points P10-P12. Average vertical deformation rates during the time period of measurement are greatest at point P7, with rates reaching $1.6 \mathrm{~cm} / \mathrm{yr}$. The maximum average settlement rate measured by GSSP data at point P8 is $1.3 \mathrm{~cm} / \mathrm{yr}$. After sequential excavation of the crossover cavern was completed in March 2019, InSAR-derived deformation showed continued subsidence until the end of the timeseries in July 2019. This post-excavation subsidence occurs at lower rates near points that undergo minimal pre-excavation deformation and is slightly faster at points that undergo greater pre-excavation deformation. 

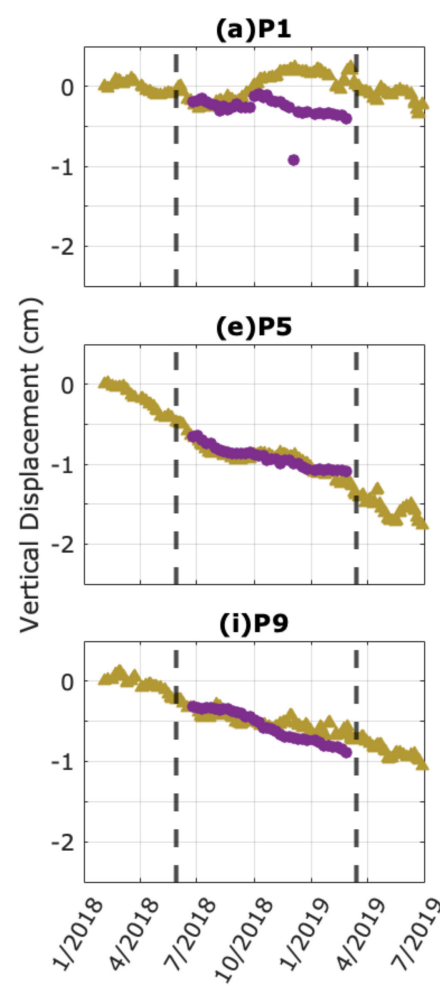

(b)P2

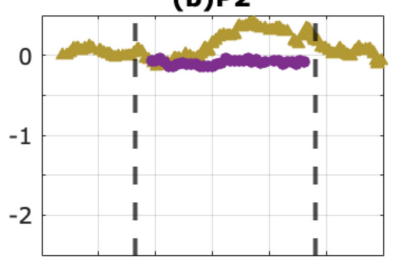

(f)P6

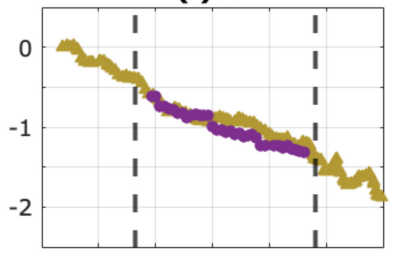

(j)P10

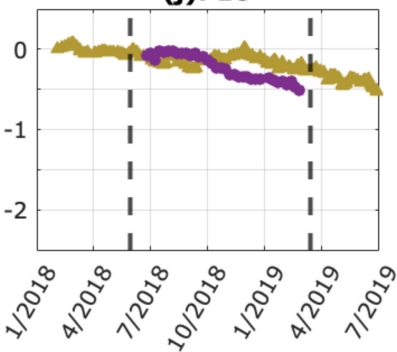

(c)P3

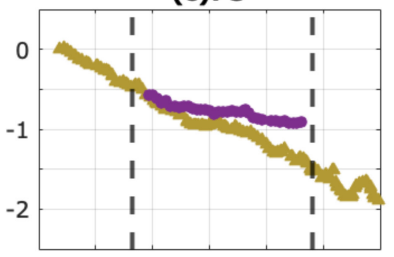

(g)P7

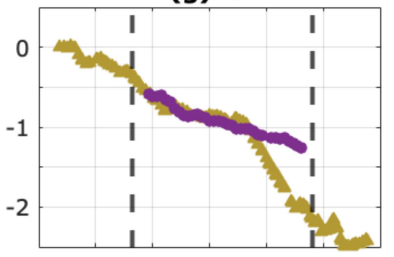

(k)P11

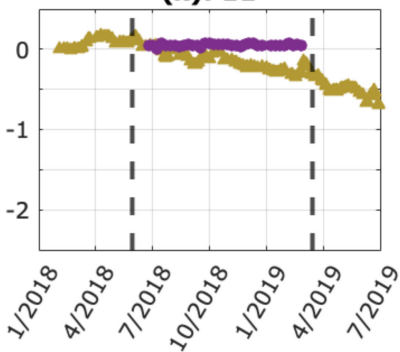

(d)P4

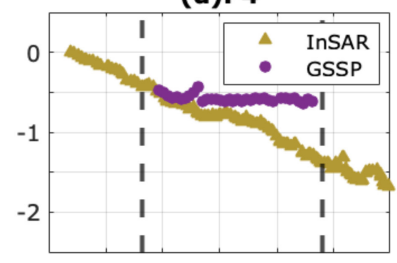

(h)P8

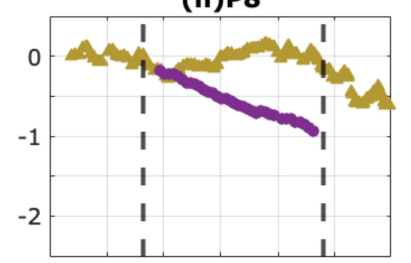

(I)P12

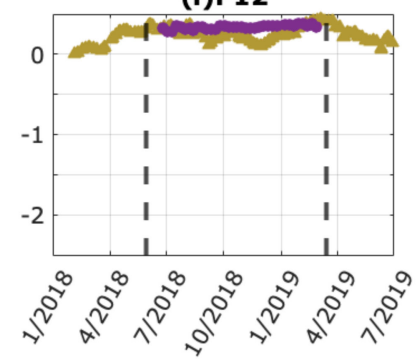

Figure 9. (a-1) Comparison of vertical InSAR deformation and ground-based data from points indicated in Figure 8b. InSAR measurements span 3 February 2018 to 28 June 2019. Ground-based data acquired between 25 June 2018 and 25 February 2019. Vertical dashed lines represent the initiation and completion of the crossover cavern sequential excavation on 30 May 2018 and 14 March 2019.

\section{Discussion}

Urban excavation processes induce ground deformation through the collapse of soils into underground voids or by the extraction of groundwater in unconsolidated deposits. This deformation can cause damage to roads, buildings, and utility lines. It is therefore critical to control the ground deformation within certain limits, especially in urban environments with overlying infrastructure. InSAR exploits the phase shift between SAR acquisitions and is a powerful technique for measuring ground settlement over time. However, the urban environment poses unique challenges to a single sensor and single platform InSAR analysis. Multiplatform InSAR time-series provide an opportunity to overcome the obstacles presented by urban noise and spatially narrow study areas.

Multiplatform InSAR time-series analysis reveals the timing and magnitude of subsidence associated with the excavation of portions of the RCTC subway extension in downtown Los Angeles. While ground-based data were focused on deformation related to the sequential excavation of the crossover cavern, InSAR data reveal vertical deformation on the western side of the cavern began in early 2018, months before sequential excavation of the cavern initiated (Figure 9c-g). This is likely due in part to the boring of the twin tunnels and cut and cover excavation at the 2nd and Broadway station, which began construction in early 2016 and finished excavation in July 2018 [54]. This is further supported by the presence of vertical and horizontal surface deformation located directly above the station (Figures 6 and $7 \mathrm{~b}$ ). Similar deformation patterns are observed from the start of cavern excavation (Figure 10) and extend past its completion (Figure 11). The settlement would also be triggered by any dewatering that occurred within the shallow perched aquifer or deeper regional aquifer, in which case the extent and magnitude of subsidence are primarily controlled by geology and aquifer storage geometry $[53,58,60]$. Time dependent soil consolidation [83] due to dewatering or other groundwater regime 
disturbance could explain the continued subsidence after the completion of the crossover cavern excavation. The duration of continued subsidence would depend on the amount of clay within the drained sediments [10,84-88], as clays are more compressible and possess a lower hydraulic conductivity than larger grain sizes [89]. There would also be potential for hydro-mechanically coupled ground rebound post groundwater table recovery [90].

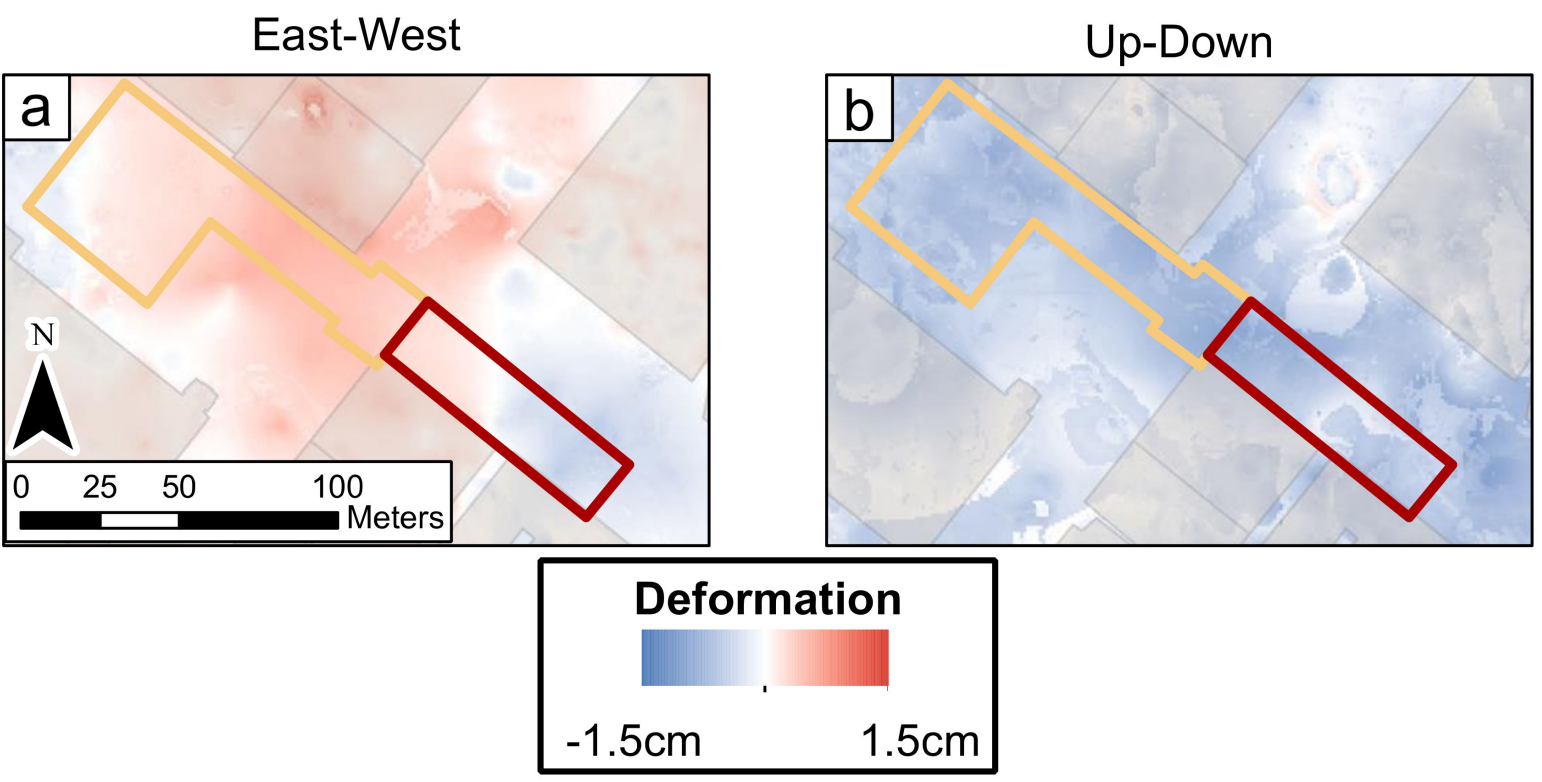

Figure 10. (a,b) Vertical and East-West horizontal deformation spanning initial crossover cavern excavation from 5 June 2018 to 11 November 2018. Displacement measured by combined Sentinel-1 and COSMO-SkyMed time-series.

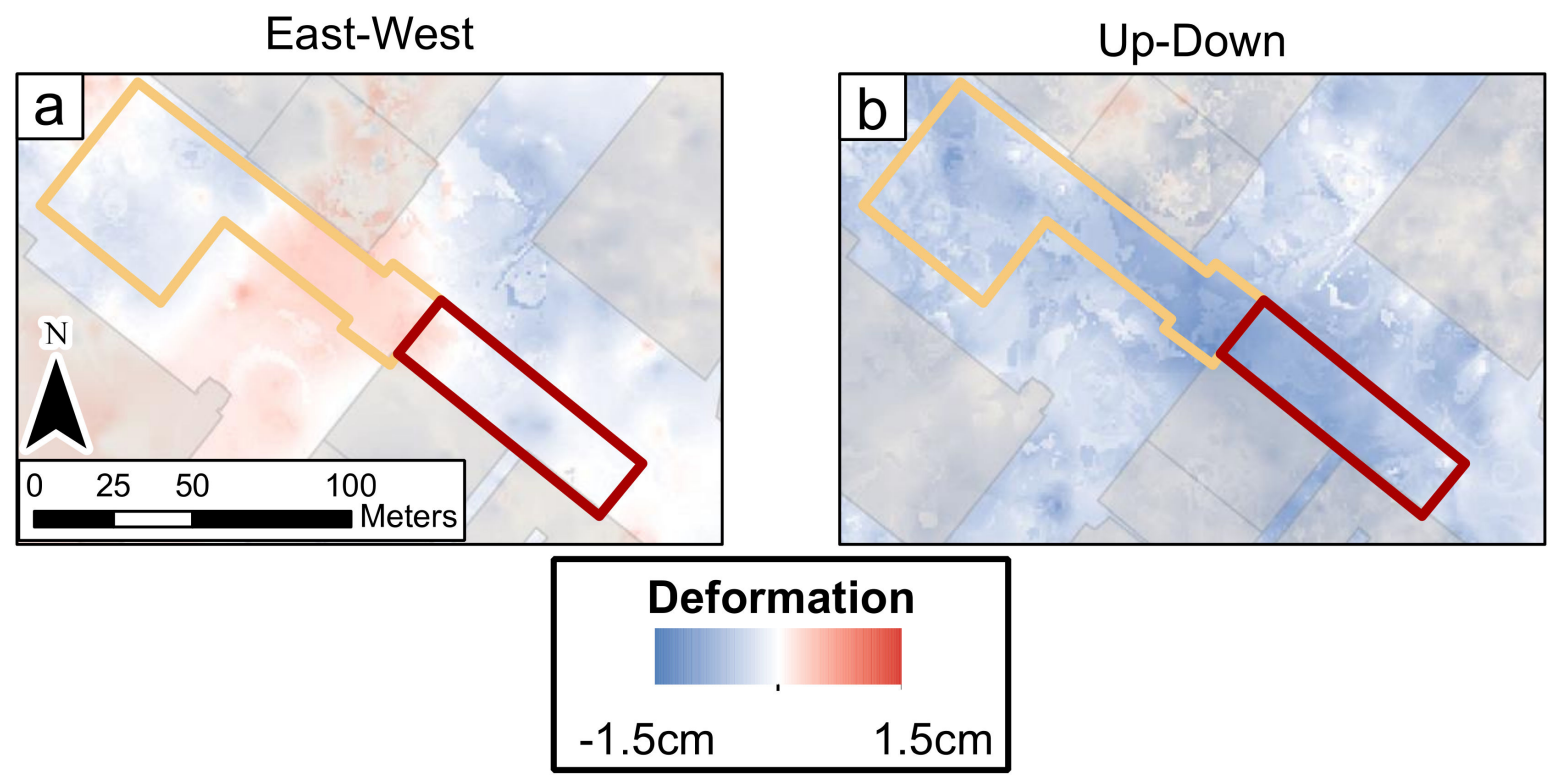

Figure 11. $(\mathbf{a}, \mathbf{b})$ Vertical and East-West horizontal deformation spanning the final portion of crossover cavern excavation from 27 February 2019 to 3 July 2019. Displacement measured by combined Sentinel-1 and COSMO-SkyMed time-series.

While the subsidence signal was clearly captured by InSAR, measurement accuracy was not consistent with the ground-based data at all locations. The single largest measurement difference occurred at point $\mathrm{P} 1$ due to an apparent outlier measurement of the ground-based data in December 2018. Point P8 possesses the most consistent discrepancies 
between the InSAR and GSSP datasets (Figure 9h). These discrepancies are attributed to limited PS pixel coverage, as Sentinel-1 provided the only PS pixels near the center of the crossover cavern (Figure $4 \mathrm{~b}$ ). Since these data possess the lowest spatial resolution of all input datasets (Table 1), measurements near this portion of the cavern rely on only a handful of PS pixels. These PS pixels appear not to capture the full magnitude of subsidence, as average and maximum residuals show a consistent underestimation of settlement near the intersection of Harlem Place and 2nd Street (Figure 8). InSAR calculations slightly overestimate uplift observed at points P1 and P2 in Fall 2018. The fact that uplift is observed in both the InSAR and GSSP datasets, along with a decrease in subsidence rate at points P3-P7 around the same time, indicate that the signal is not simply noise. One potential source of the decreased subsidence rates could be the installation of ground support during the sequential excavation. Such supports are exposed to the least amount of stress directly after installation near the face of the excavation but are subject to deformation as stress increases while excavation continues. Though the tunnel supports undergo deformation themselves, surface deformation would take place at a lower rate than it would for an unsupported excavation.

UAVSAR data produced more PS pixels along the crossover cavern, especially on the westbound side of 2nd Street toward Spring Street (Figure 4e,f). InSAR and GSSP data are in good agreement in this area aside from point P7, which possesses the largest overestimation of settlement by the InSAR data (Figures $8 \mathrm{~b}$ and $9 \mathrm{~g}$ ). The increase in InSAR measured subsidence at P7 takes place during the time period in which UAVSAR data are available (16 November 2018 to 21 February 2019). The overestimation can be attributed in part to the relatively poor temporal resolution of the UAVSAR datasets, as only four scenes are available during the period of interest. Such coarse temporal resolution increases the difficulty of accurately calculating and removing atmospheric and other noise sources and makes transient surface changes more difficult to identify. This difficulty is visually apparent in the North-South displacements (Figure 6b), which are primarily controlled by the UAVSAR datasets. The calculated North-South displacements resemble that of a subsidence signal, where horizontal motion is directed toward a plane centered at the point of maximum subsidence, but the N-S horizontal deformation is spatially inconsistent relative to the smoother E-W horizontal displacements (Figure 6a) that are better captured by satellite data with higher temporal resolution. Additionally, L-band wavelength sensors, while able to maintain coherence over longer timespans than C-band or X-band sensors, are known to possess less accurate LOS deformation measurements compared to shorter wavelength sensors [91]. Other sources of artifact inducing noise may include thermal expansion and contraction of buildings [59,76,92], surface changes due to ongoing construction related to the cut and cover of the 2nd and Broadway station, interpolation error within the LOS time-series input, other urban noise [59,76], or discrepancies related to wavelength-dependent scattering phenomena [58]. The impact of artifacts within the dataset could be partially mitigated by applying a $4 \mathrm{D}$ filter that can remove random noise from low magnitude subsidence events [60]. Timing of the initiation of subsidence could be better constrained by analysis of archival SAR data.

The InSAR PS post-processing algorithm shown here is specifically designed for application to deformation events in which the majority of displacement occurs in a single direction, which is subsidence for the case study shown here. As the MinA algorithm succeeds in calculating 3D displacement data by assuming minimum acceleration in all directions, it is not well suited for application to dynamic deformation events, such as landslides, where large magnitudes of vertical and horizontal displacements can occur simultaneously [93-95]. Interpolation of each dataset also presents potential sources of error in cases of spatially heterogeneous deformations that are not accurately captured by available PS pixels. A high PS pixel density across InSAR datasets is also required to carry out distance weighting with sufficient LOS viewing constraints. Here it is assumed that all sensor wavelengths are equally accurate and precise in their ability to capture deformation magnitudes at their PS pixel locations, though this may not be true in all situations, and 
more research is required to better quantify measurement uncertainty when combining multiple InSAR datasets of different wavelengths.

\section{Conclusions}

Combined satellite and airborne SAR data from $\mathrm{X}, \mathrm{C}$, and L band sensors reveal 3D deformation surrounding the 2 nd and Broadway subway station and the adjacent rail crossover cavern in downtown Los Angeles, encompassing an area of $30,000 \mathrm{~m}^{2}$ with maximum vertical and horizontal deformations reaching $2.5 \mathrm{~cm}$ and $1.7 \mathrm{~cm}$, respectively. Vertical displacements calculated by combining six paths of InSAR data were in good agreement with available ground-based data, within $5 \mathrm{~mm}$ on average. InSAR calculation accuracy was observed to decrease in areas with less PS pixel coverage. UAVSAR data provided the necessary constraint of N-S horizontal deformation but were limited by low temporal resolution. Both interpolating and distance weighting InSAR datasets overcame challenges presented by limited overlapping PS pixel coverage.

These results support the application of the distance-weighted MinA algorithm to small magnitude, spatially acute subsidence events given input data with sufficiently dense PS pixel spacing relative to the size and shape of ground deformation and diverse LOS viewing geometries. As more SAR platforms become available, including the recent launch of the SAOCOM SAR constellation and the future launch of the NASA-ISRO SAR mission, post-processing algorithms like the MinA algorithm can be used in combination with multiple SAR datasets to compare to or potentially replace ground-based geodetic systems for monitoring purposes.

Author Contributions: Conceptualization, K.W. and W.Z.; methodology, K.W.; software, K.W. and W.Z.; validation, K.W.; formal analysis, K.W., W.Z. and M.G.; investigation, K.W.; resources, K.W., W.Z. and M.G.; data curation, K.W. and W.Z.; writing-original draft preparation, K.W.; writing-review and editing, M.G. and W.Z.; visualization, K.W.; supervision, W.Z. and M.G.; project administration, W.Z. and M.G.; funding acquisition, M.G. All authors have read and agreed to the published version of the manuscript.

Funding: This work was supported by the University Transportation Center for Underground Transportation Infrastructure (UTC-UTI) at the Colorado School of Mines under Grant No. 69A3551747118 from the U.S. Department of Transportation (DOT).

Institutional Review Board Statement: Not applicable.

Informed Consent Statement: Not applicable.

Data Availability Statement: Publicly available datasets were analyzed in this study. Sentinel-1 data can be downloaded from the Alaska Satellite Facility (https:/ / search.asf.alaska.edu/ (accessed on 1 October 2019)). UAVSAR data can be downloaded from the National Aeronautics and Space Administration (https:/ / uavsar.jpl.nasa.gov/cgi-bin/data.pl (accessed on 6 May 2020)). GPS data can be downloaded from the Nevada Geodetic Laboratory (geodesy.unr.edu/NGLStationPages / gpsnetmap/GPSNetMap.html (accessed on 25 May 2021)).

Acknowledgments: Special thanks to the National Aeronautics and Space Administration Jet Propulsion Laboratory for providing UAVSAR data. Project carried out using CSK ${ }^{\circledR}$ Products, (C) ASI (Italian Space Agency), delivered under an ASI license to use. GPS data is based on services provided by the GAGE Facility, operated by UNAVCO, Inc., with support from the National Science Foundation and the National Aeronautics and Space Administration under NSF Cooperative Agreement EAR-1724794.

Conflicts of Interest: The authors declare no conflict of interest.

\section{References}

1. Gabriel, A.K.; Goldstein, R.M.; Zebker, H.A. Mapping small elevation changes over large areas: Differential radar interferometry. J. Geophys. Res. 1989, 94, 9183-9191. [CrossRef]

2. Massonnet, D.; Feigl, K.L. Radar interferometry and its application to changes in the earth's surface. Rev. Geophys. 1998, 36, 441-500. [CrossRef] 
3. Ferretti, A.; Prati, C.; Rocca, F. Permanent scatterers in SAR interferometry. IEEE Trans. Geosci. Remote Sens. 2001, 39, 8-20. [CrossRef]

4. Hooper, A.; Zebker, H.; Segall, P.; Kampes, B. A new method for measuring deformation on volcanoes and other natural terrains using InSAR persistent scatterers. Geophys. Res. Lett. 2004, 31, 1-5. [CrossRef]

5. Burgmann, R.; Rosen, P.A.; Fielding, E.J. Synthetic aperture radar interferometry to measure earth's surface topography and its deformation. Annu. Rev. Earth Planet. Sci. 2000, 28, 169-209. [CrossRef]

6. $\quad$ Rosen, P.A.; Hensley, S.; Joughin, I.R.; Li, F.K.; Madsen, S.N.; Rodríguez, E.; Goldstein, R.M. Synthetic aperture radar interferometry. Proc. IEEE 2000, 88, 333-382. [CrossRef]

7. Pepe, A.; Calò, F. A review of interferometric synthetic aperture RADAR (InSAR) multi-track approaches for the retrieval of Earth's Surface displacements. Appl. Sci. 2017, 7, 1264. [CrossRef]

8. Short, N.; Brisco, B.; Couture, N.; Pollard, W.; Murnaghan, K.; Budkewitsch, P. A comparison of TerraSAR-X, RADARSAT-2 and ALOS-PALSAR interferometry for monitoring permafrost environments, case study from Herschel Island, Canada. Remote Sens. Environ. 2011, 115, 3491-3506. [CrossRef]

9. Wempen, J.M.; McCarter, M.K. Comparison of L-band and X-band differential interferometric synthetic aperture radar for mine subsidence monitoring in central Utah. Int. J. Min. Sci. Technol. 2017, 27, 159-163. [CrossRef]

10. Lu, Y.; Ke, C.Q.; Zhou, X.; Wang, M.; Lin, H.; Chen, D.; Jiang, H. Monitoring land deformation in Changzhou city (China) with multi-band InSAR data sets from 2006 to 2012. Int. J. Remote Sens. 2018, 39, 1151-1174. [CrossRef]

11. Solari, L.; Ciampalini, A.; Raspini, F.; Bianchini, S.; Zinno, I.; Bonano, M.; Manunta, M.; Moretti, S.; Casagli, N. Combined use of C- and X-band SAR data for subsidence monitoring in an urban area. Geosciences 2017, 7, 21. [CrossRef]

12. Du, Z.; Ge, L.; Li, X.; Ng, A.H.-M. Subsidence monitoring over the Southern Coalfield, Australia using both L-Band and C-Band SAR time series analysis. Remote Sens. 2016, 8, 543. [CrossRef]

13. Luo, X.; Wang, C.; Long, Y.; Yi, Z. Analysis of the decadal kinematic characteristics of the Daguangbao landslide using multiplatform time series InSAR observations after the Wenchuan earthquake. J. Geophys. Res. Solid Earth 2020, 125, e2019JB019325. [CrossRef]

14. Qu, T.; Xu, Q.; Liu, C.; Li, Z.; Chen, B.; Dai, K. Radar remote sensing applications in landslide monitoring with multi-platform insar observations: A case study from China. Int. Arch. Photogramm. Remote Sens. Spat. Inf. Sci. ISPRS Arch. 2019, 42, 1939-1943. [CrossRef]

15. Liu, L.; Yu, J.; Chen, B.; Wang, Y. Urban subsidence monitoring by SBAS-InSAR technique with multi-platform SAR images: A case study of Beijing Plain, China. Eur. J. Remote Sens. 2020, 53, 141-153. [CrossRef]

16. Solano-Rojas, D.E.; Wdowinski, S.; Cabral-Cano, E.; Osmanoglu, B.; Havazli, E.; Pacheco-Martioónez, J. A multiscale approach for detection and mapping differential subsidence using multi-platform InSAR products. Proc. Int. Assoc. Hydrol. Sci. 2020, 382, 173-177. [CrossRef]

17. Wu, J.; Hu, F.; Tianliang, Y. Ground subsidece monitoring along the levee of Huangpu River by multi-platform high-resolution SAR images. In Proceedings of the 2016 th International Workshop on Earth Observation and Remote Sensing Applications (EORSA), Guangzhou, China, 4-6 July 2016.

18. Bekaert, D.P.S.; Jones, C.E.; An, K.; Huang, M.H. Exploiting UAVSAR for a comprehensive analysis of subsidence in the Sacramento Delta. Remote Sens. Environ. 2019, 220, 124-134. [CrossRef]

19. Serrano-Juan, A.; Pujades, E.; Vázquez-Suñè, E.; Crosetto, M.; Cuevas-González, M. Leveling vs. InSAR in urban underground construction monitoring: Pros and cons. Case of la sagrera railway station (Barcelona, Spain). Eng. Geol. 2017, $218,1-11$. [CrossRef]

20. Motagh, M.; Djamour, Y.; Walter, T.R.; Wetzel, H.U.; Zschau, J.; Arabi, S. Land subsidence in Mashhad Valley, northeast Iran: Results from InSAR, levelling and GPS. Geophys. J. Int. 2007, 168, 518-526. [CrossRef]

21. Bürgmann, R.; Hilley, G.; Ferretti, A.; Novali, F. Resolving vertical tectonics in the San Francisco Bay Area from permanent scatterer InSAR and GPS analysis. Geology 2006, 34, 221-224. [CrossRef]

22. Catalão, J.; Nico, G.; Hanssen, R.; Catita, C. Merging GPS and atmospherically corrected InSAR data to map 3-D terrain displacement velocity. IEEE Trans. Geosci. Remote Sens. 2011, 49, 2354-2360. [CrossRef]

23. Henderson, S.T.; Pritchard, M.E. Time-dependent deformation of Uturuncu volcano, Bolivia, constrained by GPS and InSAR measurements and implications for source models. Geosphere 2017, 13, 1834-1854. [CrossRef]

24. Hu, J.; Ding, X.L.; Li, Z.W.; Zhang, L.; Zhu, J.J.; Sun, Q.; Gao, G.J. Vertical and horizontal displacements of Los Angeles from InSAR and GPS time series analysis: Resolving tectonic and anthropogenic motions. J. Geodyn. 2016, 99, 27-38. [CrossRef]

25. Poland, M.P.; Bürgmann, R.; Dzurisin, D.; Lisowski, M.; Masterlark, T.; Owen, S.; Fink, J. Constraints on the mechanism of long-term, steady subsidence at Medicine Lake volcano, northern California, from GPS, leveling, and InSAR. J. Volcanol. Geotherm. Res. 2006, 150, 55-78. [CrossRef]

26. Akbarimehr, M.; Motagh, M.; Haghshenas-Haghighi, M. Slope stability assessment of the sarcheshmeh landslide, northeast Iran, investigated using InSAR and GPS observations. Remote Sens. 2013, 5, 3681-3700. [CrossRef]

27. Dzurisin, D.; Lisowski, M.; Wicks, C.W. Continuing inflation at Three Sisters volcanic center, central Oregon Cascade Range, USA, from GPS, leveling, and InSAR observations. Bull. Volcanol. 2009, 71, 1091-1110. [CrossRef]

28. Xue, X.; Freymueller, J.; Lu, Z. Modeling the Posteruptive Deformation at Okmok Based on the GPS and InSAR Time Series: Changes in the Shallow Magma Storage System. J. Geophys. Res. Solid Earth 2020, 125, e2019JB017801. [CrossRef] 
29. Papoutsis, I.; Papanikolaou, X.; Floyd, M.; Ji, K.H.; Kontoes, C.; Paradissis, D.; Zacharis, V. Mapping inflation at Santorini volcano, Greece, using GPS and InSAR. Geophys. Res. Lett. 2013, 40, 267-272. [CrossRef]

30. Gudmundsson, S.; Sigmundsson, F.; Carstensen, J.M. Three-dimensional surface motion maps estimated from combined interferometric synthetic aperture radar and GPS data. J. Geophys. Res. Solid Earth 2002, 107, ETG 13-1-ETG 13-14. [CrossRef]

31. Hu, X.; Lu, Z.; Pierson, T.C.; Kramer, R.; George, D.L. Combining InSAR and GPS to Determine Transient Movement and Thickness of a Seasonally Active Low-Gradient Translational Landslide. Geophys. Res. Lett. 2018, 45, 1453-1462. [CrossRef]

32. Chang, W.L.; Smith, R.B.; Farrell, J.; Puskas, C.M. An extraordinary episode of Yellowstone caldera uplift, 2004-2010, from GPS and InSAR observations. Geophys. Res. Lett. 2010, 37, 6-11. [CrossRef]

33. Johanson, I.A.; Bürgmann, R. Creep and quakes on the nothern transition zone of the San Andreas fault from GPS and InSAR data. Geophys. Res. Lett. 2005, 32, 1-5. [CrossRef]

34. Gourmelen, N.; Amelung, F.; Lanari, R. Interferometric synthetic aperture radar-GPS integration: Interseismic strain accumulation across the Hunter Mountain fault in the eastern California shear zone. J. Geophys. Res. Solid Earth 2010, 115, 1-16. [CrossRef]

35. Manzo, M.; Ricciardi, G.P.; Casu, F.; Ventura, G.; Zeni, G.; Borgström, S.; Berardino, P.; Del Gaudio, C.; Lanari, R. Surface deformation analysis in the Ischia Island (Italy) based on spaceborne radar interferometry. J. Volcanol. Geotherm. Res. 2006, 151, 399-416. [CrossRef]

36. Pritchard, M.E.; Simons, M.; Rosen, P.A.; Hensley, S.; Webb, F.H. Co-seismic slip from the 1995 July 30 Mw = 8.1 Antofagasta, Chile, earthquake as constrained by InSAR and GPS observations. Geophys. J. Int. 2002, 150, 362-376. [CrossRef]

37. Xiong, L.; Xu, C.; Liu, Y.; Wen, Y.; Fang, J. 3D displacement field of wenchuan earthquake based on iterative least squares for virtual observation and GPS/inSAR observations. Remote Sens. 2020, 12, 977. [CrossRef]

38. Delouis, B.; Giardini, D.; Lundgren, P.; Salichon, J. Joint inversion of InSAR, GPS, teleseismic, and strong-motion data for the spatial and temporal distribution of earthquake slip: Application to the 1999 İzmit mainshock. Bull. Seismol. Soc. Am. 2002, 92, 278-299. [CrossRef]

39. Yin, Y.; Zheng, W.; Liu, Y.; Zhang, J.; Li, X. Integration of GPS with InSAR to monitoring of the Jiaju landslide in Sichuan, China. Landslides 2010, 7, 359-365. [CrossRef]

40. Tong, X.; Sandwell, D.T.; Smith-Konter, B. High-resolution interseismic velocity data along the San Andreas Fault from GPS and InSAR. J. Geophys. Res. Solid Earth 2013, 118, 369-389. [CrossRef]

41. Wright, T.J.; Parsons, B.E.; Lu, Z. Toward mapping surface deformation in three dimensions using InSAR. Geophys. Res. Lett. 2004, 31, 1-5. [CrossRef]

42. Fialko, Y.; Sandwell, D.; Simons, M.; Rosen, P. Three-dimensional deformation caused by the Bam, Iran, earthquake and the origin of shallow slip deficit. Nature 2005, 435, 295-299. [CrossRef]

43. Ezquerro, P.; Del Soldato, M.; Solari, L.; Tomás, R.; Raspini, F.; Ceccatelli, M.; Fernández-Merodo, J.A.; Casagli, N.; Herrera, G. Vulnerability assessment of buildings due to land subsidence using insar data in the ancient historical city of pistoia (Italy). Sensors 2020, 20, 2749. [CrossRef] [PubMed]

44. Fialko, Y.; Simons, M.; Agnew, D. The complete (3-D) surface displacement field in the epicentral area of the 1999 Mw7.1 Hector Mine earthquake, California, from space geodetic observations. Geophys. Res. Lett. 2001, 28, 3063-3066. [CrossRef]

45. Hu, J.; Li, Z.W.; Ding, X.L.; Zhu, J.J.; Zhang, L.; Sun, Q. 3D coseismic Displacement of 2010 Darfield, New Zealand earthquake estimated from multi-aperture InSAR and D-InSAR measurements. J. Geod. 2012, 86, 1029-1041. [CrossRef]

46. Hu, J.; Ding, X.L.; Li, Z.W.; Zhu, J.J.; Sun, Q.; Zhang, L. Kalman-Filter-Based Approach for Multisensor, Multitrack, and Multitemporal InSAR. IEEE Trans. Geosci. Remote Sens. 2013, 51, 4226-4239. [CrossRef]

47. Hu, J.; Li, Z.W.; Ding, X.L.; Zhu, J.J.; Zhang, L.; Sun, Q. Resolving three-dimensional surface displacements from InSAR measurements: A review. Earth-Sci. Rev. 2014, 133, 1-17. [CrossRef]

48. Dai, K.; Liu, G.; Li, Z.; Li, T.; Yu, B.; Wang, X.; Singleton, A. Extracting vertical displacement rates in Shanghai (China) with multi-platform SAR images. Remote Sens. 2015, 7, 9542-9562. [CrossRef]

49. Gray, L. Using multiple RADARSAT InSAR pairs to estimate a full three-dimensional solution for glacial ice movement. Geophys. Res. Lett. 2011, 38, 1-6. [CrossRef]

50. Fuhrmann, T.; Garthwaite, M.C. Resolving three-dimensional surface motion with InSAR: Constraints from multi-geometry data fusion. Remote Sens. 2019, 11, 241. [CrossRef]

51. Zhu, W.; Zhang, X.; Liu, Z.; Zhu, Q. Spatiotemporal Characterization of Land Subsidence in Guandu (China) Revealed by Multisensor InSAR Observations. J. Sens. 2020, 2020, 8855364. [CrossRef]

52. Samsonov, S.; d'Oreye, N. Multidimensional time-series analysis of ground deformation from multiple InSAR data sets applied to Virunga Volcanic Province. Geophys. J. Int. 2012, 191, 1095-1108. [CrossRef]

53. Samsonov, S.V.; Tiampo, K.F.; Feng, W. Fast subsidence in downtown of Seattle observed with satellite radar. Remote Sens. Appl. Soc. Environ. 2016, 4, 179-187. [CrossRef]

54. Pepe, A.; Solaro, G.; Calò, F.; Dema, C. A Minimum Acceleration Approach for the Retrieval of Multiplatform InSAR Deformation Time Series. IEEE J. Sel. Top. Appl. Earth Obs. Remote Sens. 2016, 9, 3883-3898. [CrossRef]

55. Yu, L.; Yang, T.; Zhao, Q.; Liu, M.; Pepe, A. The 2015-2016 ground displacements of the Shanghai coastal area inferred from a combined COSMO-SkyMed/Sentinel-1 DInSAR analysis. Remote Sens. 2017, 9, 1194. [CrossRef]

56. Ozawa, T.; Ueda, H. Advanced interferometric synthetic aperture radar (InSAR) time series analysis using interferograms of multiple-orbit tracks: A case study on Miyake-jima. J. Geophys. Res. Solid Earth 2011, 116, 1-14. [CrossRef] 
57. Ebmeier, S.K.; Biggs, J.; Mather, T.A.; Amelung, F. Applicability of InSAR to tropical volcanoes: Insights from Central America. Geol. Soc. Spec. Publ. 2013, 380, 15-37. [CrossRef]

58. Werner, C.; Lowry, B.; Wegmuller, U.; Pugh, N.; Schrock, G.; Zhou, W. Deformation time-series derived from terrestrial radar observations using persistent scatterer interferometry in Seattle, Washington. In Proceedings of the 2016 IEEE International Geoscience and Remote Sensing Symposium (IGARSS), Beijing, China, 10-15 July 2016; pp. 6835-6838. [CrossRef]

59. Monserrat, O.; Crosetto, M.; Cuevas, M.; Crippa, B. The thermal expansion component of persistent scatterer interferometry observations. IEEE Geosci. Remote Sens. Lett. 2011, 8, 864-868. [CrossRef]

60. Wnuk, K.; Walton, G.; Zhou, W. Four-dimensional filtering of InSAR persistent scatterers elucidates subsidence induced by tunnel excavation in the Sri Lankan highlands. J. Appl. Remote Sens. 2019, 13, 034508. [CrossRef]

61. Castellazzi, P.; Martel, R.; Galloway, D.L.; Longuevergne, L.; Rivera, A. Assessing Groundwater Depletion and Dynamics Using GRACE and InSAR: Potential and Limitations. Groundwater 2016, 54, 768-780. [CrossRef] [PubMed]

62. Donnellan, A.; Ludwig, L.G.; Parker, J.W.; Rundle, J.B.; Wang, J.; Pierce, M.; Blewitt, G.; Hensley, S. Potential for a large earthquake near Los Angeles inferred from the 2014 La Habra earthquake. Earth Space Sci. 2015, 2, 378-385. [CrossRef]

63. Schaefer, L.N.; Lu, Z.; Oommen, T. Post-eruption deformation processes measured using ALOS-1 and UAVSAR InSAR at Pacaya Volcano, Guatemala. Remote Sens. 2016, 8, 73. [CrossRef]

64. Schaefer, L.N.; Lu, Z.; Oommen, T. Dramatic volcanic instability revealed by InSAR. Geology 2015, 43, 743-746. [CrossRef]

65. Wnuk, K.; Wauthier, C. Surface deformation induced by magmatic processes at Pacaya Volcano, Guatemala revealed by InSAR. J. Volcanol. Geotherm. Res. 2017, 344, 197-211. [CrossRef]

66. Hu, X.; Bürgmann, R. Rheology of a Debris Slide From the Joint Analysis of UAVSAR and LiDAR Data. Geophys. Res. Lett. 2020, 47, 1-9. [CrossRef]

67. Delbridge, B.G.; Bürgmann, R.; Fielding, E.; Hensley, S.; Schulz, W.H. Three-dimensional surface deformation derived from airborne interferometric UAVSAR: Application to the Slumgullion Landslide. J. Geophys. Res. Solid Earth 2016, 121, 3951-3977. [CrossRef]

68. Hensley, S.; Wheeler, K.; Sadowy, G.; Jones, C.; Shaffer, S.; Zebker, H.; Miller, T.; Heavey, B.; Chuang, E.; Chao, R.; et al. The UAVSAR instrument: Description and first results. In Proceedings of the 2008 IEEE Radar Conference, Rome, Italy, 26-30 May 2008.

69. Rosen, P.A.; Hensley, S.; Wheeler, K.; Sadowy, G.; Miller, T.; Shaffer, S.; Muellerschoen, R.; Jones, C.; Zebker, H.; Madsen, S. Uavsar: A new NASA airborne SAR system for science and technology research. In Proceedings of the 2006 IEEE Conference on Radar, Verona, NY, USA, 24-27 April 2006.

70. Hensley, S.; Zebker, H.; Jones, C.; Michel, T.; Muellerschoen, R.; Chapman, B. First deformation results using the NASA/JPL UAVSAR instrument. In Proceedings of the 2009 2nd Asian-Pacific Conference on Synthetic Aperture Radar, Xi'an, China, 26-30 October 2009.

71. Baker, G. Regional Connector Transit Project Quarterly Project Status Report, March 2020. Available online: https:/ / media.metro. net/2020/March-2020-Regional-Connector-QPSR.pdf (accessed on 15 October 2020).

72. Zheng, H.; Bragard, C.; Calvo, C.H.; Mooney, M.; Gutierrez, M. Observed Performance and Analysis of SEM Cavern Construction in Downtown Los Angeles. J. Geotech. Geoenvironmental Eng. 2021, 147, 05021011. [CrossRef]

73. Khorrami, M.; Alizadeh, B.; Tousi, E.G.; Shakerian, M.; Maghsoudi, Y.; Rahgozar, P. How groundwater level fluctuations and geotechnical properties lead to asymmetric subsidence: A PSInSAR analysis of land deformation over a transit corridor in the Los Angeles metropolitan area. Remote Sens. 2019, 11, 377. [CrossRef]

74. Blewitt, G.; Hammond, W.; Kreemer, C. Harnessing the GPS Data Explosion for Interdisciplinary Science. Eos 2018, $99,485$. [CrossRef]

75. Hudnut, K.; King, N.; Aspiotes, A.G.; Borsa, A.A.; Determan, D.N.; Galetzka, J.E.; Stark, K.F. SCIGN USGS GPS Network-MTA1Civic Center MTA P.S., The GAGE Facility operated by UNAVCO, Inc., GPS/GNSS Observations Dataset. 2006. Available online: https:/ / doi.org/10.7283/T53X84XV (accessed on 24 October 2021).

76. Wegmüller, U.; Werner, C. Mitigation of thermal expansion phase in persistent scatterer interferometry in an urban environment. In Proceedings of the 2015 Joint Urban Remote Sensing Event (JURSE), Lausanne, Switzerland, 30 March-1 April 2015.

77. Werner, C.; Wegmüller, U.; Strozzi, T.; Wiesmann, A. GAMMA SAR and interferometric processing software. In Proceedings of the ERS-Envisat Symposium, Gothenburg, Sweden, 16-20 October 2000; pp. 211-219.

78. Wegnüller, U.; Werner, C.; Strozzi, T.; Wiesmann, A.; Frey, O.; Santoro, M. Sentinel-1 Support in the GAMMA Software. Procedia Comput. Sci. 2016, 100, 1305-1312. [CrossRef]

79. Tikhonov, A.N.; Arsenin, V.Y. Solution of Ill-Posed Problems; Winston/Wiley: Washington, DC, USA, 1977.

80. Hansen, P.C.; O'leary, D.P. The Use of the L-Curve in the Regularization of Discrete Ill-Posed Problems. SIAM J. Sci. Comput. 1993, 14, 1487-1503. [CrossRef]

81. Rezghi, M.; Hosseini, S.M. A new variant of L-curve for Tikhonov regularization. J. Comput. Appl. Math. 2009, 231, 914-924. [CrossRef]

82. Hansen, P.C. REGULARIZATION TOOLS: A Matlab package for analysis and solution of discrete ill-posed problems. Numer. Algorithms 1994, 6, 1-35. [CrossRef]

83. Terzaghi, K. Principles of soil mechanics, IV—Settlement and consolidation of clay. Eng. News Record 1925, 95, 874-878. 
84. Meldebekova, G.; Yu, C.; Li, Z. Quantifying Ground Subsidence Associated with Aquifer Overexploitation Using Space-Borne Radar Interferometry in Kabul, Afghanistan. Remote Sens. 2020, 12, 2461. [CrossRef]

85. Wanwan, Z.; Yinghai, K.; Huili, G.; Lin, Z.; Beibei, C. Monitoring of land surface deformation in Beijing with time-series InSAR technique based on multi-band InSAR data using RADARSAT-2 and TERRASAR-X. In Proceedings of the 20164 th International Workshop on Earth Observation and Remote Sensing Applications (EORSA), Guangzhou, China, 4-6 July 2016.

86. Chaussard, E.; Amelung, F.; Abidin, H.; Hong, S.H. Sinking cities in Indonesia: ALOS PALSAR detects rapid subsidence due to groundwater and gas extraction. Remote Sens. Environ. 2013, 128, 150-161. [CrossRef]

87. Bonì, R.; Herrera, G.; Meisina, C.; Notti, D.; Béjar-Pizarro, M.; Zucca, F.; González, P.J.; Palano, M.; Tomás, R.; Fernández, J.; et al. Twenty-year advanced DInSAR analysis of severe land subsidence: The Alto Guadalentín Basin (Spain) case study. Eng. Geol. 2015, 198, 40-52. [CrossRef]

88. Chaussard, E.; Wdowinski, S.; Cabral-Cano, E.; Amelung, F. Land subsidence in central Mexico detected by ALOS InSAR time-series. Remote Sens. Environ. 2014, 140, 94-106. [CrossRef]

89. Chilingarian, G.V.; Knight, L. Relationship Between Pressure and Moisture Content of Kaolinite, Illite, and Montmorillonite Clays. Am. Assoc. Pet. Geol. Bull. 1960, 44, 101-106.

90. Chen, C.T.; Hu, J.C.; Lu, C.Y.; Lee, J.C.; Chan, Y.C. Thirty-year land elevation change from subsidence to uplift following the termination of groundwater pumping and its geological implications in the Metropolitan Taipei Basin, Northern Taiwan. Eng. Geol. 2007, 95, 30-47. [CrossRef]

91. Sandwell, D.T.; Myer, D.; Mellors, R.; Shimada, M.; Brooks, B.; Foster, J. Accuracy and resolution of ALOS interferometry: Vector deformation maps of the father's day intrusion at Kilauea. IEEE Trans. Geosci. Remote Sens. 2008, 46, 3524-3534. [CrossRef]

92. Goel, K.; Gonzalez, F.R.; Adam, N.; Duro, J.; Gaset, M. Thermal dilation monitoring of complex urban infrastructure using high resolution SAR data. In Proceedings of the International Symposium on Geoscience and Remote Sensing (IGARSS), Quebec City, QC, Canada, 13-18 July 2014; pp. 954-957.

93. Lowry, B.W.; Baker, S.; Zhou, W. A case study of novel landslide activity recognition using ALOS-1 InSAR within the ragged mountain Western Hillslope in Gunnison county, Colorado, USA. Remote Sens. 2020, 12, 1969. [CrossRef]

94. Lowry, B.; Gomez, F.; Zhou, W.; Mooney, M.A.; Held, B.; Grasmick, J. High resolution displacement monitoring of a slow velocity landslide using ground based radar interferometry. Eng. Geol. 2013, 166, 160-169. [CrossRef]

95. Hu, X.; Bürgmann, R.; Schulz, W.H.; Fielding, E.J. Four-dimensional surface motions of the Slumgullion landslide and quantification of hydrometeorological forcing. Nat. Commun. 2020, 11, 1-9. [CrossRef] [PubMed] 